\title{
MEASURING THE PERFORMANCE OF XYZ GOVERNMENT AGENCY WITH THE BASIS OF MALCOLM BALDRIGE METHOD
}

\author{
Kriswidanto Oktavianus, Partiwi Sri Gunani, Ambarwati Rita \\ Institute of Technology, Surabaya, Indonesia \\ *E-mail: oktavianuskriswidanto@gmail.com \\ ORCID: 0000-0002-3966-0394
}

\begin{abstract}
Government agency is collective designation which includes work unit and organizational unit of ministries or departments, non-departmental government institution, secretariat of state high institution, and other central and regional government agencies; including state-owned enterprises, state-owned legal entities, and regional-owned enterprises. One of the very effective models in improving the quality of performance of an agency is by using the Malcolm Baldrige Criteria for Performance Excellence. This research was conducted with the aim of: 1) measuring the performance of $X Y Z$ Government Agency so that their performance consistency can be monitored and 2) finding out the opportunities and obstacles in measuring the performance of $X Y Z$ Government Agency by using the Malcolm Baldrige Quality Award (MBNQA) criteria. The type of this research is descriptive research that uses $\mathrm{XYZ}$ Government Agency as the research object. The measurement conducted in this research applies the Malcolm Baldrige method. The findings showed that the criteria with the highest percentage score is operation (39.8\%) and the lowest percentage score is strategy $(35.1 \%)$. The total score is 377.5 from a maximum score of 1000 points. It showed that the performance of XYZ Government Agency is at the level of "initial growth" (scale point of 376475).
\end{abstract}

\section{KEY WORDS}

Government, agency, performance, Malcolm Baldrige.

Government agency is collective designation which includes work unit and organizational unit of ministries or departments, non-departmental government institution, secretariat of state high institution, and other central and regional government agencies; including state-owned enterprises, state-owned legal entities, and regional-owned enterprises. One of government agencies is XYZ Government Agency which is currently focused on improving the performance of human resources which is one of the main factors in sustaining the implementation of the industrial revolution. Currently, human resources are one of the growth determinants of industries other than investment and technology. The availability of competent industrial human resources will encourage the increase of productivity and provide more competitiveness in the industry. It is also proven that $85 \%$ of graduates of Vocational High School, Chemical Analysis High School, and Industrial Technology High School are absorbed in employment after graduation. The reason of high work absorption for graduates is that Vocational High School and Polytechnic in Government Institutions $X Y Z$ have applied the basis of competency and link-and-match to the industry so that the graduates really have competencies that are in accordance with what the industry needs (Ngadi, 2014).

The statement above explains that the human resources currently needed are human resources who have competence in utilizing digital technology. One of the programs carried out by XYZ Government Agency is retraining and reskilling, commonly called skill for competence. Retraining is very important for the productivity of any organization considering the technological changes that are taking place in the world of work. It means that workers must be trained to acquire the skills and knowledge needed to be able to meet these changes and perform roles assigned to them in the organization to achieve organizational goals (Oyitso \& Olomukoro, 2012). In addition, reskilling is an activity to improve the ability of 
systems and information technology and rearrange existing procedures (Widilestari, 2011). Thus, it can be concluded that competence must be increased as well as the skills of human resources in order to improve their performance and productivity. Improving the quality of human resources will have an impact on improving the quality of an agency or a company. Therefore, improving the quality of an agency or company requires the right model to process an agency or company. One of the very effective models in improving the quality of performance is the Malcolm Baldrige Criteria for Performance Excellence. Increasingly quality human resources will also make the quality of an agency or company better.

Malcolm Baldrige is one tool that can be used to identify and evaluate the performance of an organization or work unit. The Malcolm Baldrige Criteria for Performance Excellence (MBCfPE) method is based on organizational diagnostics with the basis of organizational processes and results. MBCfPE is able to identify strengths and opportunities for improvement from various areas of the organization (Purbajati et al, 2014). Previous studies that have proven the use of Malcolm Baldrige include Ekowati (2012) which explained that performance measurement using Malcolm Baldrige is quite effective. Similarly, previous research conducted by Renita and Maukar (2016) showed that study programs measured using Malcolm Baldrige are at the industry leader level. It means that the measurement using the Malcolm Baldrige method is quite effective and well used. In addition, Hasyim (2018) also stated the same thing that the use of the Malcolm Baldrige method is quite effective. The difference between previous research and current research is in the use of research method in which previous research did not only explain one method of performance measurement but also explained about other performance measurements such as balanced scorecard and others.

Internal assessment is one way for $X Y Z$ Government Agency from various groups to conduct assessments so that they can improve the performance of the agency to achieve excellent performance. The arising problem is the number of government agency that do not know the formulation or measurement system of the final score that states the performance level of the company. Based on these problems, a system that can facilitate companies in conducting internal assessments using the MBCfPE method is needed. This research was conducted with the aim of measuring the performance of XYZ Government Agency so that their performance consistency can be monitored.

\section{METHODS OF RESEARCH}

This research is a descriptive research which is intended to capture individual and group phenomena and certain situations that occur accurately (Sulistiyanto, 2015). This type of descriptive research is chosen because it is a type of research that provides a description or explanation of a situation as clearly as possible without any treatment of the object under research. The objective of descriptive research is to describe systematically and accurately about the facts and characteristics of the population or about the particular field to be researched.

By using a qualitative approach and descriptive analysis, this research is intended to observe, explain, and describe in-depth things related to the research objectives. This research sought to reveal the performance of the XYZ Government Agency with the basis of the Malcolm Baldrige method. To be able to express these problems, it applies qualitative method. This is based on the consideration that a qualitative approach can reveal and explain a phenomenon more deeply. The research subject is the XYZ Government Agency.

Data collection technique of the research includes observation, interview, questionnaire, and brainstorming which are described as follows (Sugiyono, 2012): Observation; Interview; Questionnaire; Brainstorming.

The following are the steps for implementing Malcolm Baldrige as a performance measurement tool for government agency. Mathematically, the Malcolm Baldrige score on each questionnaire category variable according to Herlina \& Prasetio (2018) is obtained through the following formula: 


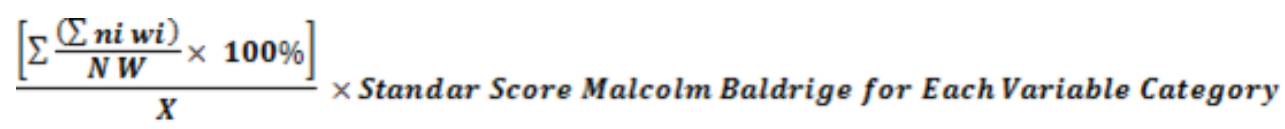

Where: $n i=$ Number of 'i' answer voters; $w i=$ Weight of 'i' answer; $N=$ Total number of respondents; $W=$ Weight of the most answer; $X=$ The total number of questions in each category of variables.

Table 1 - Operational Variables

\begin{tabular}{|c|c|c|}
\hline Variables & Sub-Variables & $\begin{array}{r}\text { Indicators } \\
\end{array}$ \\
\hline \multirow{2}{*}{ Leadership } & 1. Senior leader & $\begin{array}{l}\text { 1. Vision and values } \\
\text { 2. Communication and organizational } \\
\text { performance }\end{array}$ \\
\hline & 2. Governance and social responsibility & $\begin{array}{l}\text { 1. Organizational management } \\
\text { 2. Legal behavior and ethics } \\
\text { 3. Support for key community }\end{array}$ \\
\hline \multirow[b]{2}{*}{ Strategic planning } & 1. Strategy development & 1. Development process \\
\hline & 2. Strategy dissemination & $\begin{array}{l}\text { 1. Strategic objectives } \\
\text { 2. Development and dissemination of } \\
\text { action plans }\end{array}$ \\
\hline \multirow[b]{2}{*}{ Community focus } & 1. Market and community knowledge & 1. Market and community knowledge \\
\hline & 2. Community relations and satisfaction & $\begin{array}{l}\text { 1. Development of public relations } \\
\text { 2. Determination of community } \\
\text { satisfaction }\end{array}$ \\
\hline \multirow{2}{*}{$\begin{array}{l}\text { Knowledge measurement, } \\
\text { analysis and management }\end{array}$} & $\begin{array}{l}\text { 1. Measurement, analysis, and } \\
\text { improvement of organizational } \\
\text { performance }\end{array}$ & $\begin{array}{l}\text { 1. Performance measurement } \\
\text { 2. Performance analysis }\end{array}$ \\
\hline & $\begin{array}{l}\text { 2. Information management, information } \\
\text { technology, and knowledge }\end{array}$ & $\begin{array}{l}\text { 1. Availability of data and information } \\
\text { 2. Organizational knowledge }\end{array}$ \\
\hline \multirow[t]{2}{*}{ Workforce focus } & 1. Workforce engagement & $\begin{array}{l}\text { 1. Employee enrichment } \\
\text { 2. Development of employees and } \\
\text { leaders } \\
\text { 3. Assessment of employee } \\
\text { involvement } \\
\text { 4. Capability and capacity of the } \\
\text { workforce }\end{array}$ \\
\hline & 2. Workforce environment & 1. Workforce climate \\
\hline \multirow[t]{2}{*}{ Operation focus } & 1. Design of work systems & $\begin{array}{l}\text { 1. Core competence } \\
\text { 2. Work process design } \\
\text { 3. Readiness to respond to } \\
\text { emergencies }\end{array}$ \\
\hline & $\begin{array}{l}\text { 2. Work process management and } \\
\text { improvement }\end{array}$ & $\begin{array}{l}\text { 1. Work process management } \\
\text { 2. Work process improvement }\end{array}$ \\
\hline \multirow{5}{*}{ Results } & 1. Service and product results & 1. Service and product results \\
\hline & 2. Community focus results & 1. Community focus results \\
\hline & 3. Workforce focus results & 1. Workforce focus results \\
\hline & 4. Leadership and governance results & $\begin{array}{l}\text { 1. Process effectiveness results } \\
\text { 2. Leadership and social responsibility } \\
\text { results }\end{array}$ \\
\hline & 5. Market and financial results & 1. Market and financial results \\
\hline
\end{tabular}

Through this formula, the author looks for the percentage weight of each question, then looks for the average value of all questions in one categorical variable which is then converted into Malcolm Baldrige scores on that category variable (Giunta, 2015). In accordance with the analysis of the questionnaire results in each of the categories described previously, the results that can be seen in the MBNQA score criteria indicated by each item are scores that reflect the choice of answers from filling out the questionnaire. Meanwhile, the actual MBNQA score criteria, according to IQAF (2007) in Herlina \& Prasetio (2018), is the result term that refers to the company's output and outcomes in achieving the requirements of each of the seven criteria. The following is the table of the position or class of the company according to MBCfPE: 
Table 2 - Position or Class According to MBCfPE

\begin{tabular}{|c|c|}
\hline Position/ Class of the Company & Total Score \\
\hline Early Development & $0-275$ \\
\hline Early Result & $276-375$ \\
\hline Early Improvement & $376-475$ \\
\hline Good Performance & $476-575$ \\
\hline Emerging Industry Leader & $576-675$ \\
\hline Industry Leader & $676-775$ \\
\hline Benchmark Leader & $776-875$ \\
\hline World Leader & $876-1000$ \\
\hline
\end{tabular}

Source: Herlina and Prasetio (2018).

\section{RESULTS AND DISCUSSION}

The recapitulation of the achievement of scores from all categories based on the results of the questionnaire is presented in table 9 as follows.

Table 3 - All Category Scores Based on XYZ Government Agency Questionnaire Results in 2018

\begin{tabular}{|c|c|c|c|c|}
\hline No & Categories & $\begin{array}{l}\text { Maximum } \\
\text { Score }\end{array}$ & $\begin{array}{l}\text { Agency } \\
\text { Score }\end{array}$ & $\begin{array}{c}\text { Percentage of } \\
\text { Achievement }\end{array}$ \\
\hline 1 & Leadership & 120 & 91 & $75.8 \%$ \\
\hline 2 & Strategy & 85 & 55 & $64.7 \%$ \\
\hline 3 & Customer & 85 & 64 & $75.2 \%$ \\
\hline 4 & Knowledge Measurement, Analysis and Management & 90 & 64 & $71.1 \%$ \\
\hline 5 & Workforce & 85 & 65 & $76.4 \%$ \\
\hline 6 & Operation & 85 & 63 & $74.1 \%$ \\
\hline \multirow[t]{2}{*}{7} & Results & 450 & 311 & $69.1 \%$ \\
\hline & Total & 1000 & 713 & $71.3 \%$ \\
\hline
\end{tabular}

Table 3 shows that the total score obtained by XYZ Government Agency for the entire Malcolm Baldrige National Quality Award category, based on the results of the questionnaire, is 713 or $71.3 \%$ of the maximum score of 1000 . The category with the highest score is result (311) and the lowest is strategy (55). In addition, for the achievement percentage, the category with the largest value is workforce $(76.4 \%)$ and the smallest is strategy $(64.7 \%)$.

The frequency distribution of respondents' answers is quite varied. Respondents who gave answers with a total score equal to or greater than $71.3 \%$ (the performance of good institutions), the highest score included respondents who were aged $17-25$ years $(53.4 \%)$, were female $(80.9 \%)$, had length of employment under 1 year $(60 \%)$, had educational background of master's degree (70\%), and had type of structural official positions (60\%).

Respondents who gave answers with a total score below $71.3 \%$ (the performance of less institutions) the highest score included respondents who were aged 46-55 years $(66.7 \%)$, were male $(78.3 \%)$, had length of employment of $1-5$ years $(60.9 \%)$, had educational background of association's degree or equivalent $(73.7 \%)$, and had type of expert positions (66.7\%). The results of the frequency distribution of respondents' characteristics according to the assessment of agency performance levels can be seen in full in appendix 10.

The results of the score assessment of each item are used to calculate the achievement of the scores of all categories as shown in table 3 below.

Table 4 shows that the total score obtained by XYZ Government Agency for all categories of Malcolm Baldrige Criteria for Performance Excellence based on the results of interviews and document observations is 209.75 or $20.98 \%$ of the maximum score of 1000 . Category with the largest score is result (102.5) and the lowest is workforce (15). In addition, for the weight of achievement, the category with the largest value is result $(22.77 \%)$ and the smallest is leadership (17.08\%).

After the scores of each category based on the results of the questionnaire, interviews and document review are obtained, the next is conducting the average score assessment for each category using the following formula: Average score of each category= (Category 
scores from the questionnaire results $\times 1 / 3$ ) + (Category score from the interview and observation results $\times 2 / 3$ ). Achieving the average score of all categories based on that formula can be seen in table 5 .

Table 4 - All Category Scores Based on the Results of Interview and Document Observation to the XYZ Government Agency in 2018

\begin{tabular}{|c|c|c|c|c|}
\hline Categories \& Items & $\begin{array}{l}\text { Maximum } \\
\text { Score }\end{array}$ & Weight & $\begin{array}{l}\text { Item } \\
\text { Score }\end{array}$ & $\begin{array}{l}\text { Category } \\
\text { Score }\end{array}$ \\
\hline 1. Leadership & 120 & $17.08 \%$ & & 20.5 \\
\hline 1.1 Senior leader & 70 & $15 \%$ & 10.5 & \\
\hline 1.2 Governance and social responsibility & 50 & $20 \%$ & 10 & \\
\hline 2. Strategy & 85 & $20.29 \%$ & & 17.25 \\
\hline 2.1 Strategy development & 40 & $15 \%$ & 6 & \\
\hline 2.2 Strategy implementation & 45 & $25 \%$ & 11.25 & \\
\hline 3. Customer & 85 & $20.29 \%$ & & 17.25 \\
\hline 3.1 Customer voice & 45 & $25 \%$ & 11.25 & \\
\hline 3.2 Customer engagement & 40 & $15 \%$ & 6 & \\
\hline 4. Knowledge Measurement, Analysis, and Management & 90 & $20 \%$ & & 18 \\
\hline $\begin{array}{l}\text { 4.1 Measurement, analysis, and improvement of organizational } \\
\text { performance }\end{array}$ & 45 & $15 \%$ & 6.75 & \\
\hline $\begin{array}{l}\text { 4.2 Knowledge, information and information technology } \\
\text { management }\end{array}$ & 45 & $25 \%$ & 11.25 & \\
\hline 5. Workforce & 85 & $17.64 \%$ & & 15 \\
\hline 5.1 Workforce environment & 40 & $15 \%$ & 6 & \\
\hline 5.2 Workforce engagement & 45 & $20 \%$ & 9 & \\
\hline 6. Operation & 85 & $22.64 \%$ & & 19.25 \\
\hline 6.1 Work process & 45 & $25 \%$ & 11.25 & \\
\hline 6.2 Operational effectiveness & 40 & $20 \%$ & 8 & \\
\hline 7. Results & 450 & $22.77 \%$ & & 102.5 \\
\hline 7.1 Process and service outcome & 120 & $20 \%$ & 24 & \\
\hline 7.2 Customer focus outcome & 80 & $35 \%$ & 28 & \\
\hline 7.3 Workforce focus outcome & 80 & $15 \%$ & 12 & \\
\hline 7.4 Leadership and governance outcome & 80 & $20 \%$ & 16 & \\
\hline 7.5 Financial and marketing outcome & 90 & $25 \%$ & 22.5 & \\
\hline Total & 1000 & $20.98 \%$ & & 209.75 \\
\hline
\end{tabular}

Table 5 - Average Score of All Categories of Malcolm Baldrige Criteria for Performance Excellence Based on Questionnaire, Interview, and Document Observation Results of XYZ Government Agency in 2018

\begin{tabular}{|c|c|c|c|c|c|}
\hline Categories & $\begin{array}{c}\text { Maximum } \\
\text { Point }\end{array}$ & $\begin{array}{c}\text { Category Point from } \\
\text { the Questionnaire } \\
\text { Results }\end{array}$ & $\begin{array}{c}\text { Category Point from the } \\
\text { Interview and } \\
\text { Observation Results }\end{array}$ & $\begin{array}{c}\text { Average of } \\
\text { Category } \\
\text { Point }\end{array}$ & Percentage \\
\hline Leadership & 120 & 91 & 20.50 & 44.00 & $36.67 \%$ \\
\hline Strategy & 85 & 55 & 17.25 & 29.83 & $35.10 \%$ \\
\hline Customer & 85 & 64 & 17.25 & 32.83 & $38.63 \%$ \\
\hline $\begin{array}{c}\text { Knowledge } \\
\begin{array}{c}\text { Measurement, Analysis } \\
\text { and Management }\end{array}\end{array}$ & 90 & 64 & 18.00 & 33.33 & $37.04 \%$ \\
\hline Workforce & 85 & 65 & 15.00 & 31.67 & $37.25 \%$ \\
\hline Operation & 85 & 63 & 19.25 & 33.83 & $39.80 \%$ \\
\hline Results & 450 & 311 & 102.50 & 172.00 & $38.22 \%$ \\
\hline Total & 1000 & 713 & 209.75 & 377.50 & $37.75 \%$ \\
\hline
\end{tabular}

The table 5 shows that the total score achieved by XYZ Government Agency is 377.50. It means that by using agency performance assessment based on the Malcolm Baldrige Criteria for Performance Excellence, XYZ Government Agency achieve average predicate and is included in the category of early improvement (scale points 376-475). Early improvement means that $X Y Z$ Government Agency is in an initial position to increase in the service sector. Generally, the performance of XYZ Government Agency is quite good even though there are still gaps between reality and expectations. Some categories also still show a fairly high gap in the sub-categories of strategy $(35.1 \%)$ and leadership $(36.67 \%)$. 
Therefore, improvements need to be prioritized in those categories. More specific recommendations can be drawn up based on the data obtained through questionnaire and interview.

After determining the performance predicate and level of $X Y Z$ Government Agency according to the Malcolm Baldrige Criteria for Performance Excellence, the next step was analyzing the relationship between the process dimension categories and the result categories. The analysis was carried out by carrying out the Pearson correlation test on the data from the questionnaire.

Table 6 - Relationship between the Process Dimension Categories and the Result Categories of XYZ Government Agency in 2018

\begin{tabular}{|c|c|c|c|c|}
\hline No & Process Dimension Categories & $\begin{array}{c}\text { Significance }(\mathrm{p}- \\
\text { value })\end{array}$ & $\begin{array}{c}\text { Correlation } \\
\text { Coefficient }\end{array}$ & $\begin{array}{c}\text { Strength of } \\
\text { Relationship }\end{array}$ \\
\hline 1 & Leadership & .001 & .627 & Strong \\
\hline 2 & Strategy & .001 & .716 & Strong \\
\hline 3 & Customer & .001 & .633 & Strong \\
\hline 4 & Knowledge Measurement, Analysis, and \\
Management & .001 & .642 & Strong \\
\hline 5 & Workforce & .001 & .767 & Very Strong \\
\hline 6 & Operation & .001 & .690 & Strong \\
\hline
\end{tabular}

Drawing the conclusions by referring to the basis of decision-making correlation tests in table 6 are as follows. The result variable has a significant (meaningful) relationship with all process dimension variable (significance value $(p)<0.01$ ) in which all process dimension categories have a significance value of 0.001 . Meanwhile, at the level of strength (closeness) of the relationship between the result variable and the process dimension variable, the workforce category has the highest relationship with the result category, because it has the highest correlation coefficient value of 0.767 (very strong relationship).

\section{DISCUSSION OF RESULTS}

The implementation of the XYZ Government Agency has not been fully applied in the work. This research found the fact that senior leaders had not been committed to the vision, mission, and values and had not become the "soul" of the organization. It is a necessity for senior leaders to develop their vision, mission and values and make it a "living document".

The researcher obtained information from the informant that the vision, mission and values were socialized by senior leaders to all internal stakeholders of the agency, but the translation was carried out in a less intense manner. Senior leaders need to set performance measures so that the achievement of vision, mission, and values can be measured, analyzed and improved. Based on the research findings, the size and level of success in achieving vision, mission, and values have not been established. The committee has not functioned well; although this is important to avoid the demands of customers and the public against malpractice. In assessing the Malcolm Baldrige National Quality Award, compliance with legal and ethical behavior is very important to be made and implemented by senior leaders. Regarding the achievement of senior leaders of XYZ Government Agency in the areas of vision, mission and values, they are considered to be in the early stages in a systematic approach.

In the Malcolm Baldrige Criteria for Performance Excellence, how senior leaders communicate with all levels of workforce and customers is very important. Senior leaders are expected to encourage honest and two-way communication including the use of effective social media with all workers. Another important thing is that senior leaders need to communicate important decisions and play an active role in motivating the workforce, including participating in awards and recognition programs to strengthen performance and focus on customers.

The communication problem between the leader and staff can be linked to the servqual model, which is widely known as the Gap Analysis Model. This model was developed as a 
research survey tool called servqual. This is based on the thought that consumers can evaluate the service quality of agency by comparing their perceptions and expectations regarding the service. Servqual is considered as a general measurement tool that can be used to analyze the causes of service problems and understand how service quality can be improved and refined.

Strategic planning emphasizes the importance of how an organization addresses and responds to various dynamic and difficult-to-predict environmental changes. The strategic planning process involves senior management and managers from the business unit or other key responsibility centers which are assisted by their respective staff. Malcolm Baldrige Criteria for Performance Excellence explains that the development of strategies must be a reference for organizations to prepare for the future. Strategy development is carried out by existing leaders and teams by utilizing various types of relevant estimates, projections, choices, scenarios, and information to the organization.

Strategy development can be carried out by involving the participation of external partners, customers and other stakeholders. The strategy must be able to be broadly translated by all internal and external components. Strategies are developed/ compiled to achieve a goal through a comprehensive approach.

Based on document review, the XYZ Government Agency has determined what is the agency's strategic plan. However, it encountered obstacles that the strategy plan could not be applied. The failure of the implementation of a strategy is caused by four things which include: the vision and strategy cannot be implemented, the strategy is not connected with the goals of the department, team and individuals, the strategy is not connected with the allocation of resources and the feedback is rather tactical than strategic. The main failure in carrying out the strategy is also determined by the lack of socialization strategy. Therefore, the determination of performance in the strategic planning must cover all organizational performance, human, financial, operational and business resources.

The Malcolm Baldrige Concept Criteria for Performance Excellence not only focuses on developing strategic plans, but also emphasizes the ability of organizations and leaders to disseminate these strategic plans and translate them into key indicators that are easily understood and implemented in daily activities. The dissemination of organizational strategies requires a concerted effort from senior leadership and technical leaders to create communicative media so that all parties in the organization can be involved in efforts to achieve the objectives of the strategies that have been previously set.

Basically, XYZ Government Agency already has work plans, but the plan has not synergized with the strategic planning that has been prepared. The work plan is an effort to achieve the agency's strategic objectives. The target of the strategy is set and adjusted to the vision and mission they hold. The target strategy is converted into a work plan. The work plan is then translated into all work units. Every year, the agency evaluates the work plans in order to create a learning process even though it is still in the stage of improvement and generally has not shown any innovation.

The approach of customer focus is still very lacking because it is only based on customer data and has not implemented an approach to the customer. The method that has been carried out is only limited to the field. The results of interview and document review found that data relating to service performance were reported regularly every month in each section, but that was never analyzed to determine market segmentation. Supposedly, to get to know customers more, XYZ Government Agency can approach them through the agency's internal reports from that section every month then customer segmentation can be carried out demographically. Based on the customer characteristics, the agency can carry out customer-focused marketing strategies. Every organization must have a formal process for conducting research on market condition, customer need and expectation, as well as new approaches to improve customer relationship and satisfaction.

Less optimal use of data to segment customers in the agency is caused by limited customer data contained in that section. Then, supporting data to find out customer preferences is also needed by conducting a market survey. The agency needs to identify market segments that they can serve very effectively. One of them is by identifying 
preference segments and using approaches that classify consumers demographically in which the variables are more easily measured.

The interview results also showed that the agency also carried out the strategies of gathering information and listening directly to customers at any time. However, complaint data or interview results are never routinely analyzed and evaluated to improve service performance. There is no specific approach that can determine requirements, change expectations and other things related to customers in the form of suggestion boxes and customer surveys.

$X Y Z$ Government Agency must continue to develop market-oriented service quality. The survey of service users' satisfaction levels should be conducted routinely to determine the development of service user satisfaction levels. It should refer to the organization's goals in the agency's strategic plan; i.e. by creating satisfied customers, increasing customer loyalty supported by a strategy to improve data quality for customer service, and building partnerships with customers. These are the starting points in making improvements to the customer-focused service process.

Based on the instruments owned by the agency and the work plan that has been made by each work unit, each employee should be able to take measurements independently of the results of their work; however, not all employees can do it well. One of the important notes in the accreditation surveyor's recommendations is that the employee's competency improvement is not yet optimal.

In the Malcolm Baldrige Criteria for Performance Excellence, the variables of measurement, analysis and knowledge management are divided into 2 (two) sub-variables which include measurement, analysis, and performance improvement, as well as knowledge, information and information technology management. The existence of this variable plays an important role in synergizing three variables in the Leadership Triad, which includes leadership, strategic planning and customer focus and three other variables in the Result Triad, which include focusing on the team, focusing on organizational performance processes and results. This variable is very critical to produce fact-based and knowledgedriven systems. Measurement, analysis, and knowledge management function as the foundation of a competitive performance management system.

The category of measurement, analysis and knowledge management directs how the agency can select, collect, analyze, manage and improve their data, information and knowledge assets, including how the agency manages its information technology. In addition, this category also emphasizes the importance of the agency in using review findings to improve its performance.

Management information system at $X Y Z$ Government Agency is not optimal. Currently, it is only an application for calculating costs (billing system). One sub-system that is needed by an agency management information system is a monitoring and evaluation function. The monitoring phase and evaluation of all program operations/ implementation, including planning, need to be absolutely known quickly and accurately so that decision making also becomes more precise and faster. Unlike other business processes, monitoring and evaluation in an agency require an assessment of specific indicators that are universally applicable.

If an increase in the ratio of visits to certain diseases occurs, the management of the agency, besides being obliged to inform the competent institution, can certainly prepare the facilities related to the increase in the visit. In addition, a monitoring and evaluation mechanism in the information system must be equipped with an Early Warning System that will signal performance (operational/ managerial) indicators and signals to the Key Performance Indicator so that agency management can immediately take the necessary actions.

In terms of staff recruitment, alignment with agency needs and guidelines for strategic plans are in the initial stages. This need is adjusted to the existing budget. Employee recruitment should be carried out openly with the announcement of staff receipts. Therefore, it may bring in many prospective applicants who will facilitate the selection of the best 
candidates. The most important thing is to evaluate the existing recruitment system including work systems, job satisfaction, motivation, loyalty and complaints of the employee.

$X Y Z$ Government Agency has planned organizational restructuring which refers to new regional regulations regarding the organizational structure of work procedures by placing human resources who truly have competencies and capabilities in their fields. This is intended so that service performance in XYZ Government Agency can run more optimally and deliver innovative improvement measures. If strategic objectives are established and applied to all levels of the organization, senior leaders and managers can effectively manage employees related to the implementation of tasks.

In terms of measuring the performance of human resources at XYZ Government Agency, the measure used is the assessment of the targets of employee performance, activity, education, position, work period, loyalty, and dedication to the agency. Staff-oriented performance assessment is a simple, easy and inexpensive, but subjective method. This method is usually used by small agencies that have weaknesses because they only focus on the character of the employee, not on the merits of the employee in carrying out the task.

Performance management is sufficient to support compensation practices in the form of incentives by referring to the index system. However, the amount of receipt of incentives is not satisfactory because it does not match the employee's workload. The role of senior leaders is very decisive in the management of agency human resources to achieve the vision and mission of the organization.

The limitation of human resources is one of the obstacles in the development of education and training. Most functional staff are less motivated to participate in training and human resource development activities; except that the training has something to do with their profession. The measurement and evaluation of training results regularly and periodically has not been carried out by the agency. In this case, the agency needs to pay attention to employee performance and organizational performance in designing training and evaluation. Acquisition of employee motivation to further improve their competence and quality of performance through training development activities must be improved. Senior leaders must emphasize the effectiveness of training; especially those that have the goal of increasing customer satisfaction and loyalty. The implementation of the training review and evaluation is very important to see its effectiveness.

Another important factor that must be considered is the measurement of achieving improved employee safety, security and health. Based on the research findings, the services provided to internal agency customers currently include incentives or medical services, health insurance, annual leave and pension benefits. In its implementation, there has never been a routine and periodic evaluation of agency employee satisfaction. The management should have created a system that can find out expectations and factors that affect employee satisfaction and accommodate complaints or voices of employees as internal customers.

XYZ Government Agency has started to prepare work systems for each agency work unit; however, the limitations of the agency in providing decent working facilities are still an obstacle. Due to the existing limitations, starting with improving human resource, system and work process, Government Agency XYZ began to adjust various standards and good work procedures. The process of determining the main services in XYZ Government Agency has not gone through the identification process based on planning needs which are then analyzed. In addition, it has not accommodated input from internal and external customers. An analysis of costs and benefits has also not been carried out, as a way to ensure that the decision to open the service is appropriate.

Designing the service process must consider customer input, market research, extensive testing, planned analysis and implementation. Regarding the design process, the $\mathrm{XYZ}$ Government Agency has not yet used a model. Even though this model is needed to ensure that the right decision is taken. We recommend that several analyzes including cost analysis be made. Then, the team representing customers and suppliers as process owners is selected. This team collects data with various methods such as customer voices, websites, industry trends and local markets, benchmarks, and others. The team then develops an implementation plan including appropriate training for staff and project implementation 
schedules. After that, it is evaluated to see the shortcomings then the process is permanently set.

Supporting processes and operational planning have been carried out through plan, do, check, act. However, the process is not consistent so the implementation is not optimal. The support process is determined through a planning process that encourages staff to provide high-quality services. Supporters and businesses are analyzed to ensure the process runs according to design. It uses automated data collection techniques to minimize errors and costs associated with performance measurement. Technology is integrated in business and supporting processes for accurate and efficient operations. If it matches the size of the quality cost, it can be used as an indicator of the success of the quality improvement program.

The existence of the agency is largely determined by their ability to survive in a competitive environment. Apart from having to prioritize its social functions, as a government service institution, the agency also needs to pay attention to their business functions to maintain their operations in providing services to the community.

The Malcolm Baldrige Criteria for Performance Excellence concept aims to direct the organization to have a good focus on the ongoing process, since with a good focus on work systems and work processes, it will provide added value to organizational progress and improve organizational performance results.

The organization's ability to measure performance results will be the main benchmark in improving organizational performance in the future. This is carried out through fulfilling the elements in this variable, the principles of integrated quality management or Total Quality Management.

The current development of external factors is very dynamic in which the management cannot anticipate its influence earlier. For this reason, management is required to always be responsive and adaptive, always follow and adapt to environmental conditions. Management needs to build a strong team in determining the way or approach that will be implemented to maintain and develop the organization in an ever-changing environment.

The process approach has not answered the basic requirements of the items including: performance measurement is not consistently carried out, service has not been customer oriented, access to new agency performance data can be seen in financial performance and agency service productivity performance. Service quality performance measurement only focuses on measuring service and the level of efficiency of agency services where comprehensive measurement of service quality has not been carried out.

Regarding customer performance indicators such as customer satisfaction, customer retention, customer profitability, and market share in the target segment, operational performance indicators need to be analyzed to identify customer expectations and needs and pay attention to the drivers of key customer successes such as waiting time and service time. The final conclusion of the performance measurement of the XYZ Government Agency shown by the score illustrates that the performance of the XYZ Government Agency is still not good. Therefore, proactive planning needs to be made and implemented that is not only reactive to the problem.

In the perspective of the Malcolm Baldrige Criteria for Performance Excellence system, categories are divided into leadership triad and result triad. The leadership triad (leadership, strategy, and customers) is used to emphasize the importance of leadership so that it focuses on strategy and customers. Senior leaders set direction and look for future opportunities for the organization. Meanwhile, the result triad (labor, operations, and results) encompasses every work focus process and operational process as well as the performance results achieved by the two processes. Thus, all actions in the Malcolm Baldrige criteria for Performance Excellence are directed at achieving "results"; namely a composition of product and process performance results, customer focus, workforce focus, leadership and governance, finance and markets.

The relationship between each category in the Malcolm Baldrige Criteria for Performance Excellence is defined as "mutually bound structures", which reflect the interconnected nature of the system as a whole. The two-way arrow between the process 
dimension categories and the result categories shows the importance of feedback in an effective performance management system. The highlight of the key role of integration emphasizes that there is no particular part of the system that can operate on its own.

Malcolm Baldrige Criteria for Performance Excellence is a new name used instead of Malcolm Baldridge Criteria for Performance Excellence. The use of the word framework and design changes in the Malcolm Baldrige diagram Criteria for Performance Excellence shows and emphasizes that all categories are inseparable entities within the framework of excellent performance.

It shows a strong relationship between workforce management and customer satisfaction results. These results support the service-profit chain theory and the importance of high-skilled service providers.

Building a better work system, increasing staff training, measuring and evaluating staff performance, all of which are directed in the Malcolm Baldrige Criteria for Performance Excellence, should result in staff satisfaction which will also have an impact on the satisfaction of other customers. The circular effect of staff and customer satisfaction is illustrated in the theory of service-profit chains in which policies that increase staff satisfaction (and henceforth, staff retention and loyalty) will motivate staff to increase the value and quality of their services, leading to increased customer satisfaction.

Institutional performance results are significantly related to staff and process management. This is in line with conditions where all efforts to improve the quality of services are linked to staff. Since staffs are the spearhead that directly make contact to customers, they are direct determinants of service quality. Internal quality of agency is one way to improve the quality of the work environment, which will have an impact on staff satisfaction. Therefore, it is important for the agency to increase their staff satisfaction by providing support for staff to work through communication, engagement and compensation. In addition, the agency needs to develop innovations in staff systems and work processes to improve the efficiency of their tasks.

\section{CONCLUSION}

All categories of process dimension have a significant relationship with result categories ( $p$-value $<0.01$ ). The category with the highest relationship is workforce with a correlation coefficient of 0.767 (very strong relationship). XYZ Government Agency needs to conduct routine evaluations of the recruitment system that has been available so far including work system, job satisfaction, motivation, loyalty and employee complaint. XYZ Government Agency needs to provide decent working facilities for employees so that they can carry out their work properly. XYZ Government Agency needs to build a strong leadership team in implementing several approaches with systematic method that are appropriate for implementing the process of seven criteria in the Malcolm Baldrige Criteria for Performance Excellence and implementing and evaluating organizations consistently. The agency needs to immediately implement recommendations for improvement follow-up based on the results of the Focus Group Discussion regarding the findings of this research.

\section{REFERENCES}

1. Ekowati, T. (2012). Penilaian Kinerja dengan Menggunakan Malcolm Baldrige National Quality Award untuk Meningkatkan Mutu Pelayanan. Jurnal Administrasi Kebijakan Kesehatan, 10(3), pp. 147-151.

2. Giunta, C. E. (2015). Infusing the Malcolm Baldrige National Quality Award (MBNQA) into Marketing Curriculum. Journal of Higher Education Theory and Practice, 15(4), pp. 57-63.

3. Hasyim, M. A. N. (2018). Pengukuran Kinerja Perusahaan Hotel Berdasarkan Kriteria Malcolm Baldrige. Jurnal Ecodemica, 2(1), pp. 109-116.

4. Herlina \& Prasetio, D. E. A. (2018). Penilaian Kinerja Perusahaan dengan Metode Malcolm Baldrige Criteria for Performance Excellence di PT. Daido Metal Indonesia. Jurnal Bisnis dan Manajemen, pp. 1-7. 
5. Ngadi, N. (2014). Relevansi Pendidikan Kejujuran terhadap Pasar Kerja di Kota Salatiga. Jurnal Kependudukan Indonesia, 9(1), pp. 59-70.

6. Oyitso, M. \& Olomukoro, C. O. (2012). Training and Retraining Nigeria Workers to Enhance Task Performance. Interdisciplinary Journal of Contemporary Research in Business, 4(1), pp. 69-77.

7. Purbajati, R. J., Nugraha, C. \& Arijanto, S. (2014). Sistem Perangkat Lunak untuk Internal

8. Renita, R. \& Maukar, A. L. (2016). Penilaian Kinerja dengan Menggunakan Malcolm Baldrige Education Criteria for Performance Excellence (MBECfPE) 2013-2014 pada Program Studi Teknik Industri President University. Journal of Industrial Engineering, 1(2), pp. 1-8.

9. Sugiyono. (2012). Metode Penelitian Kuantitatif, Kualitatif, dan R\&D. Bandung: Penerbit Alfabeta.

10. Sulistiyanto, S. (2015). Studi Kasus Analisis Penggunaan Media Sosial Dalam Akun Twitter @ChelseaFC_Indo. Essence Jurnal Seni, Desain, Komunikasi Peneliti Muda Vol. 1 No. 1

11. Widilestari, C. (2011). Konsep Balanced Scorecard dan Kendala Penerapannya. Jurnal STIE Semarang, 3(2), pp. 1-13. 